\title{
Profile of the Alcohols Produced in Fermentations with Malt Contaminated with Trichothecenes
}

\author{
Christian Oliveira Reinehr and Eliana Badiale Furlong* \\ Laboratório de Micotoxinas; Departamento de Química; Fundação Universidade Federal do Rio Grande; \\ dqmebf@super.furg.br; C. P. 474; 96201-900; Rio Grande - RS - Brazil
}

\begin{abstract}
In order to study the influence of mycotoxins on the production of alcohols, a fermentative process on a laboratorial scale was simulated. Malt was contaminated with deoxynivalenol and T-2 in different ratios (up to 500 ppb), according to a $3^{2}$ factorial design, and the alcohols obtained after the fermentation were determined through gas chromatography. The results showed that trichothecenes influenced the profile of the alcohols produced by Saccharomyces cerevisiae during the fermentative process of malt, especially the profile of methyl and isoamyl alcohols.
\end{abstract}

Key words: Deoxynivalenol, fermentation, malt, T-2 toxin, trichothecenes

\section{INTRODUCTION}

The presence of mycotoxins in food for human consumption could be due to fungal contamination (raw materials, semimanufactured and final products), or by the contamination of animal products, through contaminated feed consumed by the animal (Ueno, 1983). The fungi which usually contaminate vegetables and grains in the field are Fusarium, Trichoderma, Myrothecium, Stachybotrys, Cylindrocarpon and Trichothecium. Most of the described trichothecenes belong to the Fusarium species, which attack cereals in zones of temperate climate (Langseth and Rundberget, 1998).

Trichothecenes are a family of sesquiterpenoids with ester and alcohol functions, which present a double bond between carbons 9 and 10, and an epoxide ring at positions 12 and 13 of the structure, which is shown in Figure 1. The epoxide ring and the double bond in position 9 are the basic elements for toxicity; however, other substitutes and their positions and sizes also influence the degree of toxicity.

Trichothecenes can be found in several products. Studies have shown the presence of deoxynivalenol (DON) and T-2 toxin in barley and other cereals (Scott, 1990, Furlong et al., 1995, Langseth et al., 1999). Barley is used in the production of beer, which also in some cases appears to be contaminated by deoxynivalenol and nivalenol (Shim et al., 1987), and by deoxynivalenol and zearalenone (Scott et al., 1992, 1993).

Trichothecene deoxynivalenol maintains its stability after contaminated malt is fermented with this toxin, which indicates that it is not metabolized by the yeast Saccharomyces. However, it can influence the fermentative process through the blocking of any metabolic path, leading to the formation of undesirable products (Scott, 1996).

\footnotetext{
* Author for correspondence
} 


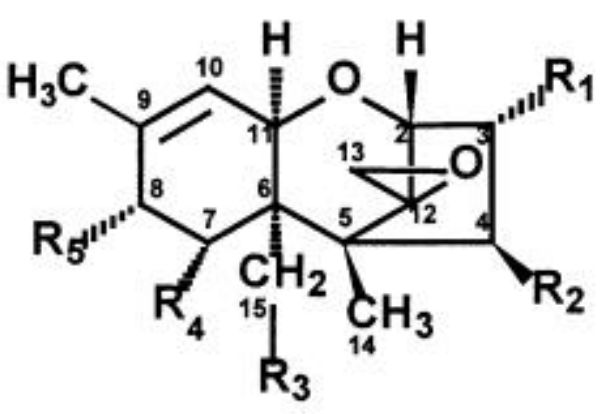

Figure 1 - Structure of the trichothecenes. Substitutes such as $\mathrm{H}, \mathrm{OH}$, acils, epoxides, esters can appear at positions 3, 4, 7, 8, 14 and 15 of the structure (Langseth and Rundberget, 1998).

In view of the fact that malt used for the industrial production of beer is often contaminated, a fermentative process was simulated with the purpose of verifying whether the presence of the mycotoxins deoxynivalenol (in virtue of its high incidence in this type of raw material) and T-2 (in virtue of its high toxicity) influence the profile of alcohols produced during alcoholic fermentation.

\section{MATERIALS AND METHODS}

\section{Reagents and samples}

All the reagents used were of analytical grade, from Merck Chemical Co. and Aldrich Chemical Co. (alcohols standards), and Sigma Chemical Co. (toxin standards). Non-contaminated malt collected at a local brewery was used. The yeast used for the fermentative process was Saccharomyces cerevisiae, obtained in dried form.

\section{Contamination and fermentation}

Non-contaminated malt was milled. To each fermentor, $20 \mathrm{~g}$ of milled malt were added. Contamination was carried out by adding the toxins in different amounts to each fermentor. A full factorial design was planned, and the degrees of contamination were as shown in Table 1. The degrees of contamination were expressed in $\mathrm{ppb}$ $\left(\mathrm{ng}_{\text {toxin }} / \mathrm{g}_{\text {malt }}\right)$. The degrees chosen are under 1000 $\mathrm{ng} / \mathrm{g}$, which is usually accepted as limit in animal feed by several countries. Two experiments were done for each combination.

A culture of Saccharomyces cerevisiae was grown overnight (ca. 18 hours) in a medium with agar $(1.75 \%)$, dextrose $(2 \%)$, peptone $(1 \%)$ and yeast extract $(1 \%)$ at $30^{\circ} \mathrm{C}$. To each fermentor with malt, $250 \mathrm{ml}$ of water were added. A 10-ml aliquot of the Saccharomyces culture was placed in each fermentor. The fermentors were closed to generate anaerobic conditions and were then placed in a shaker with temperature and agitation controllers at $30^{\circ} \mathrm{C}$ and $70 \mathrm{rpm}$. The samples were collected after $24 \mathrm{~h}$ of fermentation.

\section{Determination of the produced alcohols}

The determination of the alcohols was done in a Varian gas chromatograph - model $3400 \mathrm{CX}$ equipped with a flame ionization detector (FID) and a capillar column, model DB-FFAP Megabore (stationary phase: nitroterephtalic acid modified by polyethylene glycol). The column was of the following dimensions: $30 \mathrm{~m}$ long, $0.545 \mathrm{~mm}$ in diameter and with a $1 \mathrm{~mm}$ film thickness. The carrier gas was nitrogen $\left(\mathrm{N}_{2}\right)$, at a speed of 2 $\mathrm{ml} / \mathrm{min}$. The temperatures of the injector and the detector were both $150^{\circ} \mathrm{C}$. The initial temperature of the column was $50^{\circ} \mathrm{C}$, which lasted for 2 minutes. The temperature increased $10^{\circ} \mathrm{C} / \mathrm{min}$, to $120^{\circ} \mathrm{C}$, where it remained for a further 2 minutes a total of 11 minutes. The amount of sample injected was $1 \mu \mathrm{l}$. The alcohols produced were identified by comparing the retention times to standards, and were quantified through external standardization. The compounds verified in the chromatograms were determined by the software Varian Star version 4.51, through the peaks areas.

$\underline{\text { Table } 1 \text { - Matrix of the } 3^{2} \text { factorial design }}$

\begin{tabular}{ccc}
\hline \multirow{2}{*}{ Experiment } & \multicolumn{2}{c}{ Concentration } \\
\cline { 2 - 3 } & DON (ng/g) & T-2 (ng/g) \\
\hline 1 & 0 & 0 \\
2 & 250 & 0 \\
3 & 500 & 0 \\
4 & 0 & 250 \\
5 & 250 & 250 \\
6 & 500 & 250 \\
7 & 0 & 500 \\
8 & 250 & 500 \\
9 & 500 & 500 \\
\hline
\end{tabular}

\section{Statistical analysis}

The means, standard deviations and p-values presented were statistically determined through Analysis of Variance from the results of the experiments. The means presented in the table are the average of two experiments. 


\section{RESULTS AND DISCUSSION}

Analysing the chromatograms of the experiments 7 distinct peaks were detected, 6 of which were identified in accordance with their retention times. Fig. 2 shows a chromatogram of one of the experiments after the fermentation.

Table 2 presents the means and standard deviations in the experiments for each alcohol produced. The standard deviations were all below $10 \%$, indicating that the replicates were very close to each other. After the fermentation, it was observed that the final average of ethanol formed was $3.94 \%$, close to the concentration obtained in the usual brewing process (around 4\%).

The resume of the Analysis of Variance is presented in Table 3. As can be seen, neither deoxynivalenol nor the T-2 toxin showed any significant effect on the concentration of propyl alcohol. However, all the other alcohols were shown to be dependent upon the presence of the toxins studied. For the other four alcohols, the interaction effect was significant $(95 \%$ confidence interval), so it was of no advantage to analyse the effects separately. Consequently only the interaction effect was studied.

The production of ethanol was influenced by the presence of the mycotoxins (Fig. 3). When the T-2 toxin was present at a concentration of $500 \mathrm{ng} / \mathrm{g}$, the production of ethanol increased with increasing concentrations of DON.

When the concentration of T-2 was $250 \mathrm{ng} / \mathrm{g}$, the maximal ethanol production appeared with a higher concentration of DON or without it. Furthermore, when the T-2 toxin was absent, the concentration of ethanol was not influenced by DON. Although the concentration of ethanol presented little variation (between 3.932 and $3.944 \%$ ), the differences were statisticaly confirmed at $95 \%$ confidence interval. In industrial processes the amount of alcohol produced normally is very high, making these differences important.

Schapira et al. (1989) studied the influence of diverse mycotoxins on the malting process. They concluded that deoxynivalenol did not affect this process. Böswald et al. (1995) and Madhyastha et al. (1994) showed that the presence of deoxynivalenol did not inhibit the growth of Saccharomyces cerevisiae.

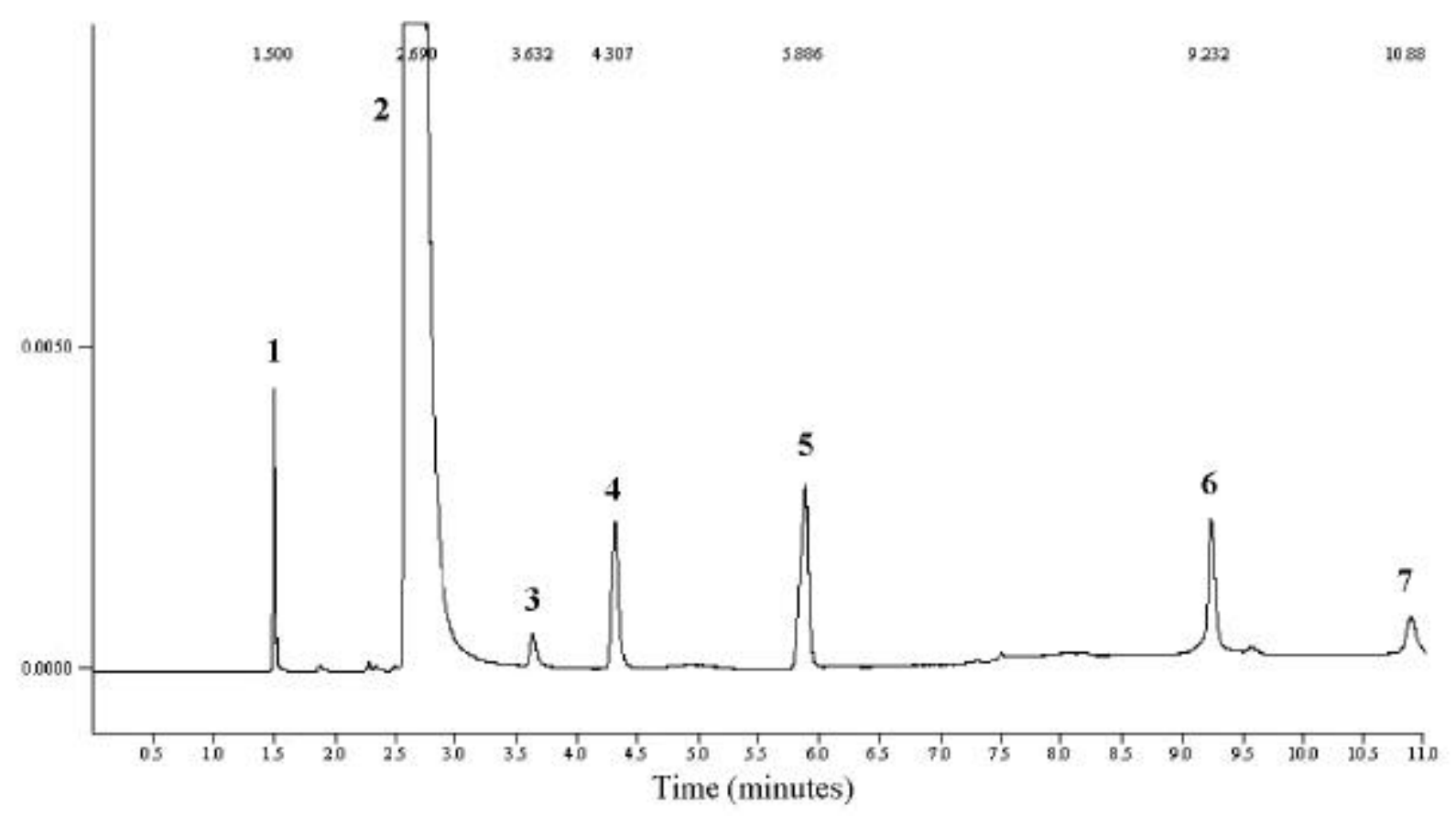

Figure 2 - Chromatogram from a sample after the fermentation. The numbered peaks are the following compounds: 1) methyl alcohol; 2) ethyl alcohol; 3) propyl alcohol; 4) isobutyl alcohol; 5) isoamyl alcohol; 6) acetic acid; 7) not identified. 
Table 2 - Means and standard deviations (SD) in the experiments, as determined by gas chromatography. The means are the average of two experiments.

\begin{tabular}{|c|c|c|c|c|c|c|}
\hline \multicolumn{2}{|c|}{ Experiment } & $\begin{array}{l}\text { Methyl } \\
\text { alcohol }\end{array}$ & $\begin{array}{c}\text { Ethyl } \\
\text { alcohol }\end{array}$ & $\begin{array}{l}\text { Propyl } \\
\text { alcohol }\end{array}$ & $\begin{array}{c}\text { Isobutyl } \\
\text { alcohol }\end{array}$ & $\begin{array}{c}\text { Isoamyl } \\
\text { alcohol }\end{array}$ \\
\hline \multirow{2}{*}{1} & Mean $(\%)$ & 0.01042 & 3.93792 & 0.00426 & 0.02013 & 0.03127 \\
\hline & SD & 0.00034 & 0.00143 & 0.00017 & 0.00014 & 0.00080 \\
\hline \multirow{2}{*}{2} & Mean $(\%)$ & 0.00846 & 3.94093 & 0.00420 & 0.02002 & 0.03016 \\
\hline & SD & 0.00001 & 0.00035 & 0.00024 & 0.00020 & 0.00013 \\
\hline \multirow{2}{*}{3} & Mean $(\%)$ & 0.00724 & 3.94092 & 0.00424 & 0.02019 & 0.03033 \\
\hline & SD & 0.00003 & 0.00033 & 0.00029 & 0.00003 & 0.00011 \\
\hline \multirow{2}{*}{4} & Mean $(\%)$ & 0.00846 & 3.94433 & 0.00403 & 0.01917 & 0.02885 \\
\hline & SD & 0.00055 & 0.00055 & 0.00000 & 0.00027 & 0.00086 \\
\hline \multirow{2}{*}{5} & Mean $(\%)$ & 0.01000 & 3.93605 & 0.00436 & 0.02008 & 0.03040 \\
\hline & SD & 0.00012 & 0.00085 & 0.00043 & 0.00012 & 0.00022 \\
\hline \multirow{2}{*}{6} & Mean $(\%)$ & 0.00814 & 3.94406 & 0.00405 & 0.01988 & 0.03030 \\
\hline & SD & 0.00010 & 0.00093 & 0.00002 & 0.00040 & 0.00007 \\
\hline \multirow{2}{*}{7} & Mean $(\%)$ & 0.00924 & 3.93230 & 0.00450 & 0.02014 & 0.03054 \\
\hline & SD & 0.00051 & 0.00046 & 0.00008 & 0.00004 & 0.00040 \\
\hline \multirow{2}{*}{8} & Mean $(\%)$ & 0.01005 & 3.94173 & 0.00419 & 0.02000 & 0.02903 \\
\hline & SD & 0.00004 & 0.00148 & 0.00022 & 0.00023 & 0.00112 \\
\hline \multirow{2}{*}{9} & Mean $(\%)$ & 0.01055 & 3.94403 & 0.00431 & 0.01967 & 0.03016 \\
\hline & SD & 0.00009 & 0.00097 & 0.00040 & 0.00014 & 0.00013 \\
\hline
\end{tabular}

Table 3 - Results of the Analysis of Variance (* Significant different at 95\% confidence interval)

\begin{tabular}{cccccc}
\hline \multirow{2}{*}{ Effect } & \multicolumn{5}{c}{ p-value } \\
\cline { 2 - 6 } & $\begin{array}{c}\text { Methyl } \\
\text { alcohol }\end{array}$ & $\begin{array}{c}\text { Ethyl } \\
\text { Alcohol }\end{array}$ & $\begin{array}{c}\text { Propyl } \\
\text { alcohol }\end{array}$ & $\begin{array}{c}\text { Isobutyl } \\
\text { alcohol }\end{array}$ & $\begin{array}{c}\text { Isoamyl } \\
\text { alcohol }\end{array}$ \\
\hline DON & $0.0008 *$ & $<0.0001 *$ & 0.9055 & 0.1894 & 0.4654 \\
T-2 & $<0.0001 *$ & $0.0095 *$ & 0.4749 & $0.0160 *$ & 0.0930 \\
Interaction & $<0.0001 *$ & $<0.0001 *$ & 0.5095 & $0.0074 *$ & $0.0217 *$ \\
\hline
\end{tabular}

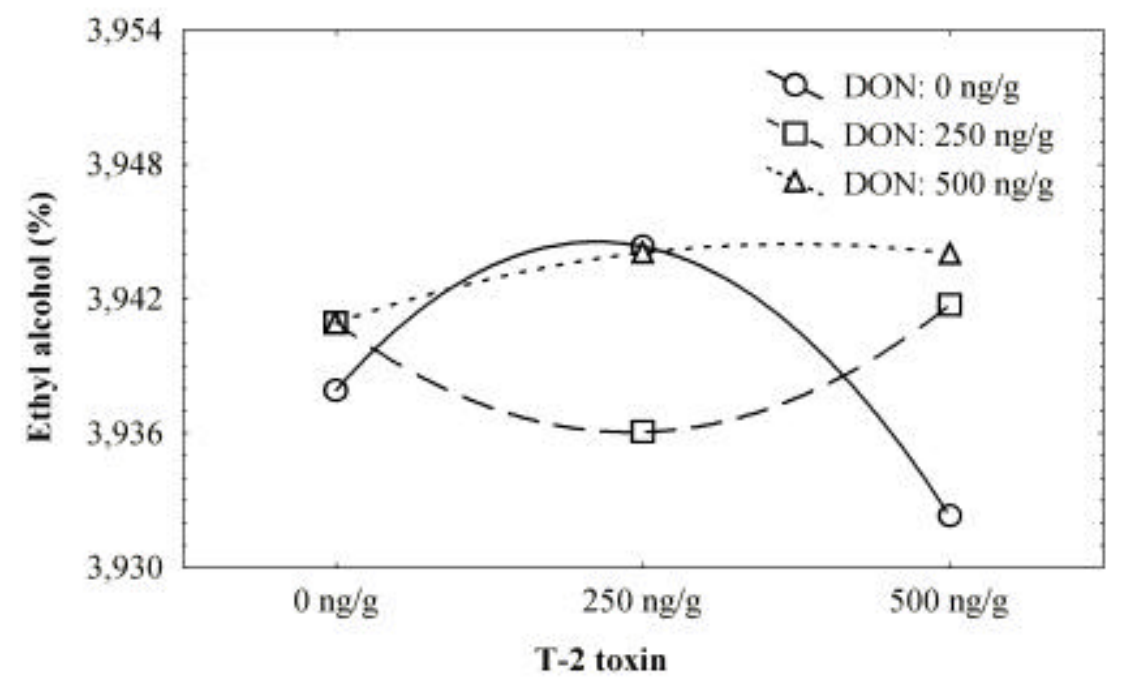

Figure 3 - Plot of means for the two-way interaction between degrees of contamination with deoxynivalenol and with T-2 toxin, showing concentration of ethyl alcohol produced. 


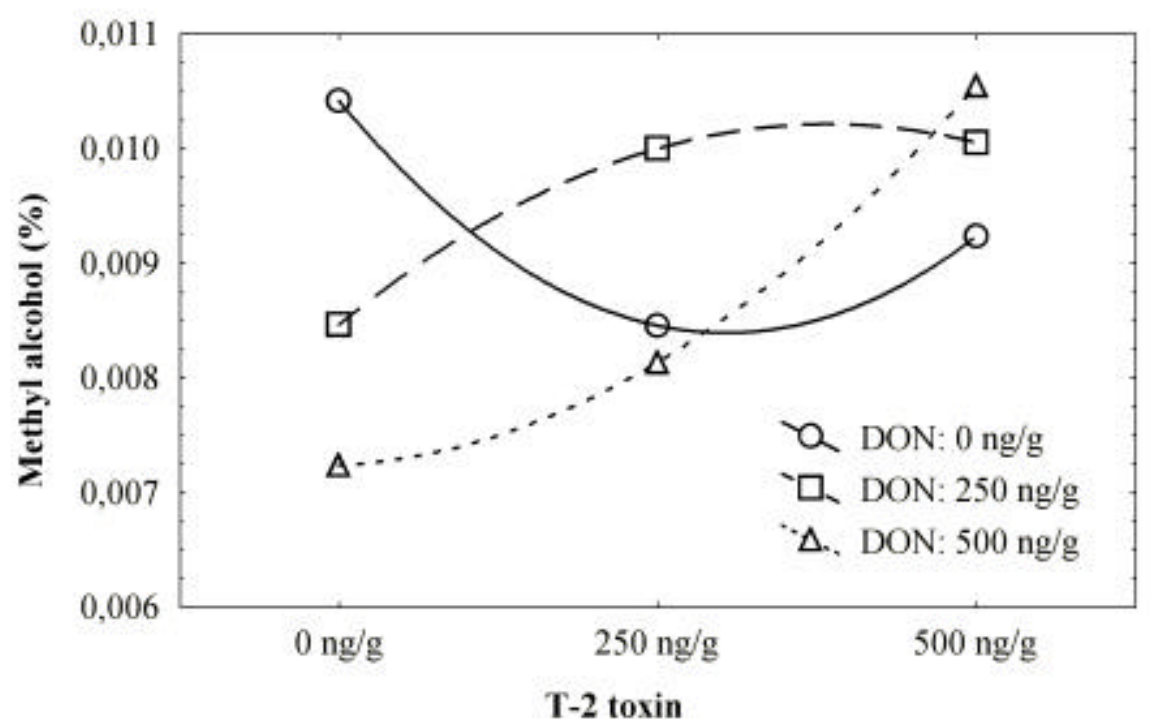

Figure 4 - Plot of means for the two-way interaction between degrees of contamination with deoxynivalenol and with T-2 toxin, showing concentration of methyl alcohol produced.

Whitehead and Flannigan (1989) showed that the DON did not affect the production of ethanol. Ethanol is produced during the exponential growth phase and the maximal ethanol concentration occurs as the culture enters the stationary phase. Ethanol production follows this pattern regardless or whether the T-2 toxin is in the medium. In mithocondria isolated from Saccharomyces cerevisiae, T-2 toxin inhibited site II of the electron transport chain and succinate dehydrogenase activity, but not NADH dehydrogenase activity (Koshinsky et al., 1992). However, in relation to the existing glucose there was a higher concentration of ethanol as the toxin T-2 inhibited the oxidative but not the fermentative metabolism. Thus, the inhibition of the mitochondrial function and an increase in the catabolism of the glucose led to a consequent higher formation of ethanol (relative to glucose). According to these statements, the production of ethanol should not be influenced by the T-2 toxin. This was not observed, because the influence of this toxin was dependent upon the presence of the other toxin. Moreover, in the study developed by Koshinsky et al. (1992), the concentration of the toxin was much higher (between 20 and $200 \mu \mathrm{g} / \mathrm{g}$ ) than that used in this study (maximal $500 \mathrm{ng} / \mathrm{g}$ ).

With regard to methanol, at the end of the fermentation there was a high variation in its concentration in the experiments (between 0.011 and $0.007 \%$ ). It was observed that there was a higher production of methanol when both toxins were absent. When T-2 was present at $500 \mathrm{ng} / \mathrm{g}$, the production of methyl alcohol increased with increasing concentrations of DON. In the absence of T-2 and when the concentration of DON increased, it was found that the production of methanol decreased (Fig. 4).

It was not clear where the methanol was coming from in this system. One hypothesis was that this comes from the esters which are formed in the enzymatic reaction between carboxyl acids (especially acetyl) with alcohols (including higher). These esters are formed during the anaerobic phase of the fermentation. Perhaps a carboxylase produced by the yeast is affected when a toxin such as DON or T-2 is present.

The concentration of isobutyl alcohol varied between 0.019 and $0.020 \%$. The most significant influence was observed when the concentration of T-2 was $250 \mathrm{ng} / \mathrm{g}$. In this case, the absence of DON caused a decrease in the production of alcohol. However, without T-2 toxin and with 500 $\mathrm{ng} / \mathrm{g}$ of it, neither the presence of deoxynivalenol nor the concentration of $\mathrm{T}-2$ significantly influenced the production of isobutyl alcohol.

With regard to isoamyl alcohol, at the end of the fermentation there was a variation in its concentration between 0.029 and $0.031 \%$. When the concentration of DON was $500 \mathrm{ng} / \mathrm{g}$, the 
production of amyl alcohol was constant, with or without T-2 toxin (Fig. 5).

The main metabolic pathway for the production of higher alcohols is related to deamination, decarboxylation and reduction of the aminoacids which are in the medium. Several enzymes play a role in these reactions, making further studies necessary to determine which enzymes are really affected by the trichothecenes. The results presented here were partially expected because fermentative metabolism was believed not to be affected by these mycotoxins. Although propyl alcohol production was not affected, different alcohols such as ethanol, methanol and other higher alcohols were differently produced with the presence of T-2 toxin and DON.

Based on these results, it was concluded that unpredictable productions of methanol and higher alcohols could be obtained depending on the presence of fungal contamination in cereals. When barley is contaminated with trichothecenes (even in low concentrations, such as $500 \mathrm{ppb}$ ), quality control must be present during brewing process, not only relative to post contamination, but also due to unexpected concentrations of alcohols.

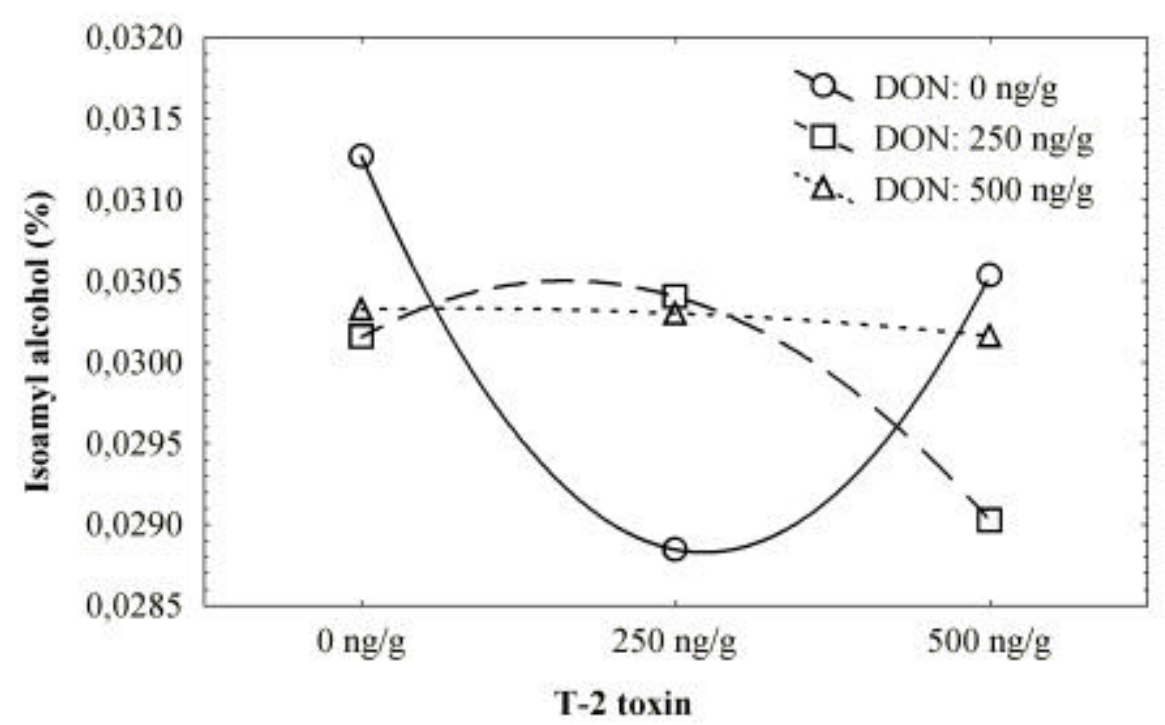

Figure 5 - Plot of means for the two-way interaction between degrees of contamination with deoxynivalenol and with T-2 toxin, showing concentration of isoamyl alcohol produced.

\section{ACKNOWLEDGEMENTS}

The financial support received from CAPES (Fundação Coordenação de Aperfeiçoamento de Pessoal de Nivel Superior) is gratefully acknowledged.

\section{RESUMO}

Os tricotecenos são metabólitos produzidos por diversos fungos, principalmente os do gênero Fusarium. As condições climáticas de diversos países, como o Brasil, favorecem o crescimento desses fungos e a produção dos tricotecenos, os quais podem estar presentes em vários cereais, como por exemplo a cevada, que pode ser utilizada em processos fermentativos visando a obtenção de álcool. Com o objetivo de estudar a influência que essas micotoxinas apresentam na produção de álcoois, um processo fermentativo em pequena escala foi simulado. Malte foi contaminado com deoxinivalenol e toxina $\mathrm{T}-2$ em diferentes quantidades (até $500 \mathrm{ppb}$ ), de acordo com um planejamento fatorial $3^{2}$, e os álcoois obtidos após a fermentação foram determinados por cromatografia gasosa. Os resultados mostraram que os tricotecenos podem influenciar o perfil dos álcoois produzidos pela levedura Saccharomyces cerevisiae durante o processo fermentativo do malte, especialmente dos álcoois metílico e isoamílico. 


\section{REFERENCES}

Böswald, C.; Engelhardt, G.; Vogel, H. and Wallnöfer, P. R. (1995), Metabolism of the Fusarium mycotoxins zearalenone and deoxynivalenol by yeast strains of technological relevance. Natural Toxins, 3, 138-144.

Furlong, E. B.; Valente-Soares, L. M.; Lasca, C. C. and Kohara, E. Y. (1995), Mycotoxins and fungi in wheat stored in elevators in the state of Rio Grande do Sul, Brazil. Food Additives and Contaminants, 12 : (5), 683-688.

Koshinsky, H. A.; Cosby, R. H. and Khachatourians, G. G. (1992), Effects of T-2 toxin on ethanol production by Saccharomyces cerevisiae. Biotechnology and Applied Biochemistry, 16 : (3), 275-286.

Langseth, W.; Bernhoft, A.; Rundberget, T.; Kosiak, B. and Gareis, M. (1999), Mycotoxin production and cytotoxicity of Fusarium strains isolated from Norwegian cereals. Mycopathologia, 144, 103-113.

Langseth, W. and Rundberget, T. (1998), Instrumental methods for determination of nonmacrocyclic trichothecenes in cereals, foodstuffs and cultures. Journal of Chromatography A, 815, 103-121.

Madhyastha, M. S.; Marquardt, R. R.; Masi, A.; Borsa, J. and Frohlich, A. A. (1994), Comparison of toxicity of different mycotoxins to several species of bacteria and yeasts: use of Bacillus brevis in a disc diffusion assay. Journal of Food Protection, 57 : (1), 48-53.

Schapira, S. F. D.; Whitehead, M. P. and Flannigan, B. (1989), Effects of the mycotoxins diacetoxyscirpenol and deoxynivalenol on malting characteristics of barley. Journal of the Institute of Brewing, 95, 415-417.

Scott, P. M. (1990), Trichothecenes in grains. Cereal Foods World, 35, 661-666.

Scott, P. M. (1996), Mycotoxins transmitted into beer from contaminated grains during brewing. Journal of AOAC International, 79 : (4), 875-882.

Scott, P. M.; Kanhere, S. R.; Daley, E. F. and Farber, J. M. (1992), Fermentation of wort containing deoxynivalenol and zearalenone. Mycotoxin Research, 8, 58-66.
Scott, P. M.; Kanhere, S. R. and Weber, D. (1993), Analysis of Canadian and imported beers for Fusarium mycotoxins by gas chromatography/mass spectrometry. Food Additives and Contaminants, 10 : (4), 381-389.

Shim, W. B.; Kim, J. C.; Seo, J. A. and Lee, Y. W. (1997), Natural occurance of trichothecenes and zearalenone in Korean and imported beers. Food Additives and Contaminants, 14 : (1), 1-5.

Ueno, Y. (1983), Trichothecenes: chemical, biological and toxicological aspects. New York: Elsevier.

Whitehead, M. P. and Flannigan, B. (1989), The Fusarium mycotoxin deoxynivalenol and yeast growth and fermentation. Journal of the Institute of Brewing, 95, 411-413.
Received: March 11, 2002; Revised: June 04, 2002; Accepted: October 24, 2003. 